\title{
Pro-apoptotic effects of Kangfuxin on human stomach cancer cells and its underlying mechanism
}

\author{
XIUYING MA ${ }^{1 *}$, JIA SUN $^{2 *}$, WEIJIAN YE ${ }^{3 *}$, YEWEI HUANG ${ }^{2}$, CONGCONG SUN $^{2}$, \\ YOULI TAO ${ }^{2}$, TAO WANG ${ }^{2}$, WEITAO CONG ${ }^{2}$ and FUNENG GENG ${ }^{1}$ \\ ${ }^{1}$ Sichuan Key Laboratory of Medical American Cockroach, Chengdu, Sichuan 610000; \\ ${ }^{2}$ College of Pharmacy, Wenzhou Medical University; ${ }^{3}$ The Second Affiliated Hospital and \\ Yuying Children's Hospital of Wenzhou Medical University, Wenzhou, Zhejiang 325000, P.R. China
}

Received July 25, 2016; Accepted March 19, 2018

DOI: $10.3892 / 01.2018 .8713$

\begin{abstract}
Kangfuxin (KFX) is an oral liquid derived from Periplaneta americana, with complex components. KFX has been demonstrated to exhibit anticancer activity in a variety of different types of tumor, including gastric cancer; however, its underlying molecular mechanism remains unclear. The present study was designed to investigate the pro-apoptotic effects of KFX on SGC-7901 cells, in order to provide a theoretical basis for clinical application. In order to clarify the pro-apoptotic effects of KFX on SGC-7901 cells, MTT analysis was conducted. To evaluate the anticancer effect of KFX, peroxisome proliferator-activated receptor (PPAR)- $\gamma$ was analyzed by reverse transcription-polymerase chain reaction. Western blot analysis was used to determine the effects of KFX on the expression of cleaved caspase-3, phosphorylated extracellular signal-regulated kinase (p-ERK), ERK, tumor protein p53 (p53), B-cell lymphoma 2 (Bcl-2), Bcl-2 associated X, interleukin (IL)-6 and IL-1 $\beta$. In addition, terminal deoxynucleotidyl-transferase-mediated dUTP nick-end labeling (TUNEL) analysis was used to detect apoptosis in SGC-7901 cells. It was revealed that PPAR- $\gamma$ was increased in SGC-7901 cells following treatment with KFX, shown by an increase in mRNA expression. Furthermore, western blot analysis identified that KFX treatment groups exhibited markedly inhibited levels of Bcl-2, IL-6, IL-1 $\beta$ and
\end{abstract}

Correspondence to: Professor Weitao Cong, College of Pharmacy, Wenzhou Medical University, Center North Road, Wenzhou, Zhejiang 325000, P.R. China

E-mail: cwt97126@126.com

Dr Funeng Geng, Sichuan Key Laboratory of Medical American Cockroach, 88 Yingmenkou Road, Chengdu, Sichuan 610000, P.R. China

E-mail: haoyishenggfn@126.com

${ }^{*}$ Contributed equally

Key words: Kangfuxin, apoptosis, proliferation, extracellular signal-regulated kinase
p-ERK, and induced p53 protein expression. Additionally, TUNEL and MTT assays demonstrated that treatment with KFX may induce SGC-7901 cell apoptosis and inhibit proliferation. In conclusion, to the best of our knowledge, the results of the present study demonstrated for the first time that KFX may induce SGC-7901 cell apoptosis and inhibit its proliferation, and this may be primarily attributed to its role in mitogen-activated protein kinase/extracellular-signal-regulated kinase kinase/ERK signaling pathway inhibition.

\section{Introduction}

Although the incidence and mortality rates have decreased globally since the second half of the twentieth century, gastric cancer still ranks as the fourth most frequently occurring and the second most lethal type of cancer worldwide, accounting for $10.4 \%$ of cancer-associated mortalities (1). Gastric cancer remains a major health concern primarily due to the slow decrease in incidence in Asia and the high rates of mortality in diagnosed gastric carcinomas in the West, despite the widespread application of innovative diagnostic and surgical techniques in clinical practice $(2,3)$. Cancer is a genetic disease that is derived from cells that accumulate mutations in essential growth regulatory genes, including oncogenes and tumor suppressor genes (4). Despite fluoropyrimidines and oxaliplatin-based chemotherapy being successfully applied for cancer treatment, a number of side effects are exhibited, including oxaliplatin-induced cumulative dosage-dependent neurotoxicity (5). Therefore, investigations into an anticancer drug that decreases the incidence of relapse and presents with fewer side effects are required.

The American cockroach (Periplaneta americana), the largest species of pest insect in the Blattidae family, is a worldwide domestic pest native to Africa that has spread throughout the world, particularly in tropical and subtropical regions (6). In China, an extract derived from the dried whole body of $P$. americana has been used in traditional Chinese medicine for the treatment of bloodstasis syndrome, acne and abdominal masses for a hundred years (7). Previous pharmacological studies have demonstrated that the crude extract of P. americana exhibits significant anticancer, anti-inflammation and tissue regeneration activities (8-10). 
With the development of traditional Chinese medicine resources, importance has increasingly been attached to their research and development. Several novel drugs, including Kangfuxin (KFX) oral liquid, Xinmailong injection and cockroach oil have been developed using $P$. americana as the raw material, with recognized pharmacological activity and clinical efficacy (11-14). A previous study revealed that $P$. americana extract exhibited significant anticancer effects on the BEL-7402/5-FU Cell line and SGC-7901 cell line $(15,16)$. However, the exact apoptotic effect of KFX remains unclear. Therefore, in the present study, the anticancer effect of KFX was investigated by focusing on its apoptotic potential in the human gastric cancer SGC-7901 cell line, as well as its effects on the mitogen-activated protein kinase/extracellular-signal-regulated kinase kinase (MEK)/extracellular signal-regulated kinase (ERK) signaling pathway.

\section{Materials and methods}

Materials. The human gastric cancer SGC-7901 cell line was obtained from the cell resource center of the Shanghai Biological Sciences Institute (Chinese Academy of Sciences, Shanghai, China). KFX oral liquid was received from Sichuan Good Doctor Pharmaceutical Group (Sichuan, China), comprising $1 \mathrm{~g} / \mathrm{ml}$ P. americana dried whole body in water.

Cell culture. SGC-7901 cells were maintained in RPMI-1640 supplemented with $10 \%$ fetal bovine serum (both Gibco; Thermo Fisher Scientific, Inc.) in a humidified atmosphere with $5 \% \mathrm{CO}_{2}$ at $37^{\circ} \mathrm{C}$. The cultured cells were passaged with $0.25 \%$ trypsin (Gibco; Thermo Fisher Scientific, Inc. Waltham, MA, USA) when cell confluence reached $\sim 80 \%$. Cells between passage numbers 3 and 10 were selected for experimentation. Before starting the experimental procedures, the desired final concentrations of $\operatorname{KFX}(0,0.25,0.5,2.5 \mathrm{mg} / \mathrm{ml})$ were achieved by diluting the stock solution $(1 \mathrm{~g} / \mathrm{ml})$ in RPMI-1640 culture medium. Then the SGC-7901 cells were placed in RPMI-1640 in the presence or absence of KFX for 12 or $24 \mathrm{~h}$. In some experiments, SGC-7901 cells were exposed to a MEK inhibitor U0126 $(0.2 \mu \mathrm{M}$, dissolved in RPMI-1640 culture medium) (Sigma-Aldrich; Merck KGaA, Darmstadt, Germany) for $12 \mathrm{~h}$. For signaling pathway analysis, SGC-7901 cells were treated with phorbol 12-myristate 13-acetate (PMA) (3 nM, dissolved in DMSO) (Sigma-Aldrich; Merck KGaA, Darmstadt, Germany), a specific activator of protein kinase $\mathrm{C}$, nuclear factor- $\mathrm{\kappa B}$ and ERK, for $12 \mathrm{~h}$ in combination with KFX treatment.

Reverse transcription-polymerase chain reaction (RT-PCR) analysis. The SGC-7901 cells were placed in RPMI-1640 in the presence or absence of $\operatorname{KFX}(0,0.25,0.5,2.5 \mathrm{mg} / \mathrm{ml})$ for 12 or $24 \mathrm{~h}$. Four $\mu \mathrm{g}$ RNA and oligo $\mathrm{dT}_{18}$ were then incubated at $80^{\circ} \mathrm{C}$ for $5 \mathrm{~min}$. The cDNA synthesis reaction was performed at $42^{\circ} \mathrm{C}$ for $1 \mathrm{~h}$ with M-MLV reverse transcriptase (cat. no., A5001; Promega Corporation), followed by incubation at $70^{\circ} \mathrm{C}$ for $15 \mathrm{~min}$ to inactivate the reverse transcriptase. Following RT, samples were diluted by adding $60 \mu \mathrm{l}$ purified water. For the PCR, PCR MasterMix (cat. no., PR1700; BioTeke Corporation, Beijing, China) was used and the reactions were performed in a T100 Thermo Cycler (Bio-Rad Laboratories) with the following profile: Incubation for $3 \mathrm{~min}$ at $95^{\circ} \mathrm{C}$, followed by 32 cycles of denaturation for $30 \mathrm{sec}$ at $95^{\circ} \mathrm{C}$, annealing for $30 \mathrm{sec}$ at $72^{\circ} \mathrm{C}$, and extension for $5 \mathrm{~min}$ at $72^{\circ} \mathrm{C}$. The products were resolved in a $1 \%$ agarose gel stained with SYBR Safe (Invitrogen; Thermo Fisher Scientific, Inc.). ImageJ software (version 1.48; National Institutes of Health, Bethesda, MD, USA) was used to quantify the bands (17). Primer sequences of peroxisome proliferator-activated receptor (PPAR)- $\gamma$ and GAPDH for RT-PCR were as follows: PPAR- $\gamma$ forward, 5'-TCT GGCCCACCAACTTTGGG-3' and reverse, 5'-CTTCACAAG CATGAACTCCA-3'; and GAPDH forward, 5'-GCCAAG GTCATCCATGACAACT-3' and reverse, 5'-GAGGGGCCA TCCACAGTCTT-3'.

Western blot analysis. SGC-7901 cells were lysed in a buffer consisting of $7 \mathrm{M}$ urea, $2 \mathrm{M}$ thiourea, $2 \%$ 3-[(3-cholamidopropyl) dimethylammonio]-1-propanesulfonate hydrate, $40 \mathrm{mM}$ Trizma base, $40 \mathrm{mM}$ dithiothreitol and $1 \%$ protease inhibitor cocktail (Sigma-Aldrich; Merck $\mathrm{KGaA}$ ). Following centrifugation at 21,885 x g for $15 \mathrm{~min}$ at $4^{\circ} \mathrm{C}$, the total protein concentration in the supernatant was determined with a Bradford protein assay (Bio-Rad Laboratories, Inc., Hercules, CA, USA). Equal amounts of protein $(50 \mu \mathrm{g} / \mathrm{lane})$ were subjected to SDS-PAGE (10\% gel) and transferred onto polyvinylidene difluoride membranes. Samples were then blocked with 5\% skimmed dried milk in Tris-buffered saline containing $0.1 \%$ TritonX-100 (TBST) at room temperature for $2 \mathrm{~h}$, and incubated overnight at $4^{\circ} \mathrm{C}$ with the following primary antibodies: Cleaved-Caspase-3 (cat. no., 9661; dilution, 1:1,000; Cell Signaling Technology Inc., Danvers, MA, USA), Bax (cat. no., ab32503; dilution, 1:1,000; Abcam), Bcl-2 (cat. no., ab59348; dilution, 1:1,000; Abcam), p53 (cat. no., 2524; dilution, 1:1,000; Cell Signaling Technology, Inc.), IL-1 $\beta$ (cat. no., ab106035; dilution, 1:1,000; Abcam;), IL-6 (cat. no., ab6672; dilution, 1:1,000; Abcam), TNF- $\alpha$ (cat. no., ab1793; dilution, 1:5,000; Abcam), p-Erk (cat. no., 9101; dilution, 1:1,000; Cell Signaling Technology, Inc.), Erk (cat. no., 9102; dilution, 1:1,000; Cell Signaling Technology, Inc.) and $\beta$-actin (cat. no., 4970; dilution, 1:1,000; Cell Signaling Technology, Inc.). The membrane was washed with TBST three times, 5 min each. Subsequently, the membrane was incubated with a horseradish peroxidase-conjugated goat-anti-mouse (cat. no., ab6789; dilution, 1:300; Abcam) or HRP-goat-anti-rabbit (cat. no., ab6721; dilution, 1:300; Abcam) for $2 \mathrm{~h}$ at room temperature. Membranes were washed with TBST three times for $5 \mathrm{~min}$ each, prior to incubation with enhanced chemiluminescence (cat. no., WBKLS0500; Merck KGaA) for $1 \mathrm{~min}$. The protein levels were normalized against that of internal protein $\beta$-actin using ImageJ software (version 1.48; National Institute of Health, Bethesda, MD, USA).

Terminal deoxynucleotidyl-transferase-mediated dUTP nick-end labeling (TUNEL) assay. The TUNEL assay was performed using a commercially available In situ Cell Death Detection kit (Roche Diagnostics GmbH; cat. no., 11684817910), according to the manufacturer's protocol, as previously described (18). SGC-7901 cells cultured on 6-mm plates were fixed with $4 \%$ paraformaldehyde solution for $30 \mathrm{~min}$ at room temperature. Following a PBS wash, cells 

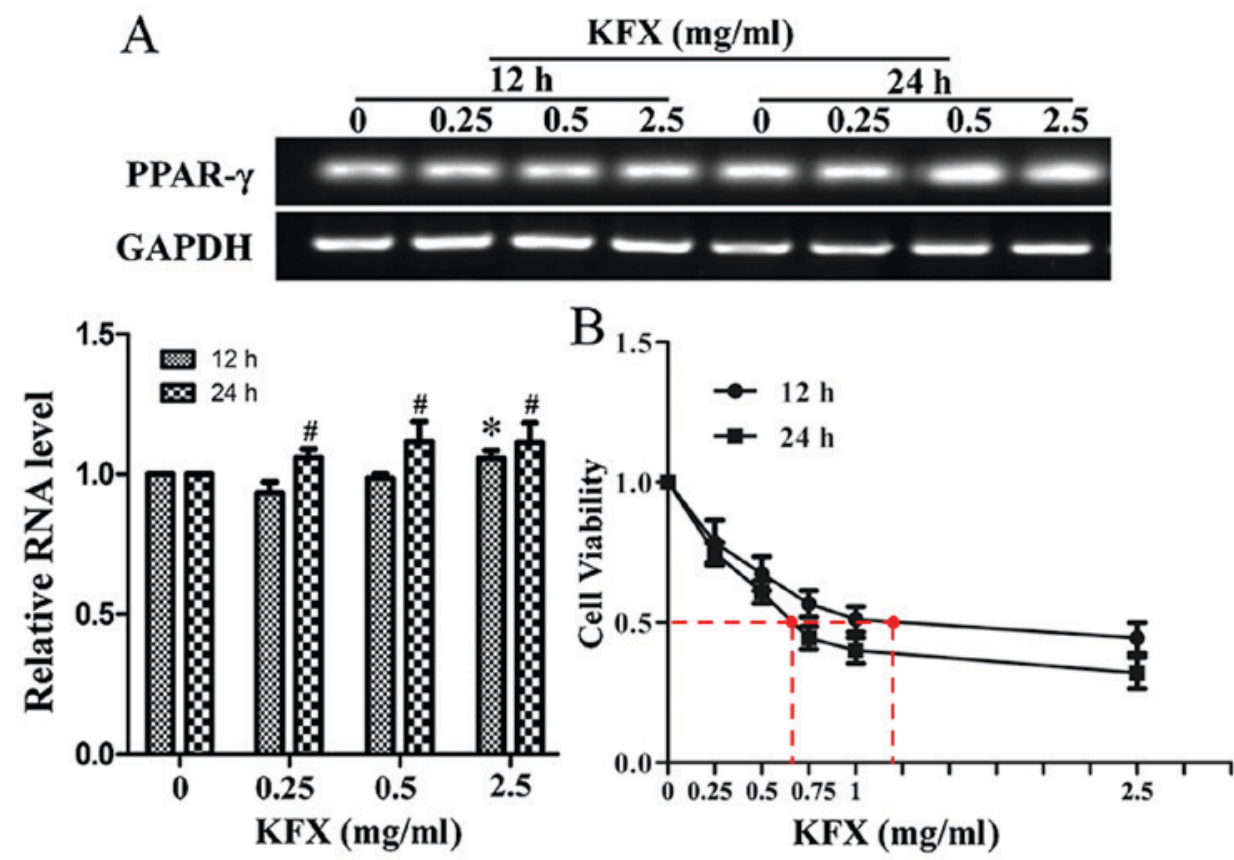

Figure 1. KFX increases PPAR- $\gamma$ mRNA expression and decreases the viability of SGC-7901 cells. (A) SGC-7901 cells were treated with KFX at different concentrations $(0,0.25,0.5$ and $2.5 \mathrm{mg} / \mathrm{ml})$ for 12 and $24 \mathrm{~h}$, and the PPAR- $\gamma$ mRNA level was analyzed by reverse transcription-polymerase chain reaction. The histogram presents the quantitative analysis of PPAR- $\gamma$ mRNA level, and the data are expressed as fold over control group; $\mathrm{n}=6$ for each group. Data are presented as the mean \pm standard error of the mean. ${ }^{*} \mathrm{P}<0.05$ compared with $\mathrm{KFX}(0 \mathrm{mg} / \mathrm{ml})$ treatment for $12 \mathrm{~h}$; $\mathrm{P}<0.05 \mathrm{compared} \mathrm{with} \mathrm{KFX} \mathrm{(0} \mathrm{mg/ml)} \mathrm{treat-}$ ment for $24 \mathrm{~h}$. (B) The anti-proliferative effect of KFX was investigated using an MTT assay. SGC-7901 cells were treated with different dosages of KFX (0, $0.05,0.15,0.25,0.5$ and $2.0 \mathrm{mg} / \mathrm{ml}$ ) for 12 and $24 \mathrm{~h} ; \mathrm{n}=6$ for each group. Data are presented as the mean \pm standard error of the mean. ${ }^{*} \mathrm{P}<0.05$ compared with KFX $(0 \mathrm{mg} / \mathrm{ml})$ treatment for $12 \mathrm{~h} ;{ }^{*} \mathrm{P}<0.05$ compared with KFX $(0 \mathrm{mg} / \mathrm{ml})$ treatment for $24 \mathrm{~h}$. KFX, Kangfuxin; PPAR- $\gamma$, peroxisome proliferator-activated receptor $\gamma$.

were treated with permeation solution $(0.1 \%$ Triton $\mathrm{X}-100$ in $0.1 \%$ sodium citrate) for $2 \mathrm{~min}$ at $4^{\circ} \mathrm{C}$. Following washing with PBS, samples were incubated with TUNEL reagent containing $10 \%$ terminal deoxynucleotidyl transferase and $2 \%$ fluorescent isothiocyanate-dUTP for $1 \mathrm{~h}$ at $37^{\circ} \mathrm{C}$. Subsequently, the cells were stained with $1 \mu \mathrm{g} / \mathrm{ml}$ DAPI for $30 \mathrm{~min}$ at room temperature to detect the cellular nuclei. Finally, the cells are mounted on coverslips with antifade mounting medium (Beyotime, P0126). Using an excitation wavelength in the range of 450-500 $\mathrm{nm}$ and detection in the range of 515-565 nm (green), the number of TUNEL-positive SGC-7901 cells and apoptotic bodies were determined. The percentage of apoptotic cells were calculated by dividing the number of TUNEL-positive cells by the total number of cells visualized in $\geq 6$ separate fields using a fluorescence microscope. Three digitized images of similar total cell numbers were selected from each cover slip for counting and averaging, and were considered as one independent experiment. Three independent experiments were then averaged and statistically analyzed.

MTT assay. SGC-7901 cells were plated in 96-well plates at a density of 5,000 cells/well in $120 \mu \mathrm{l}$ complete medium (RPMI-1640 (Gibco; Thermo Fisher Scientific, Inc.; cat. no., 11875093) supplemented with $10 \%$ fetal bovine serum (Gibco; Thermo Fisher Scientific, Inc.; cat. no., 16000044). To investigate the cytotoxic effect of KFX, SGC-7901 cells were treated with $0.00,0.25,0.5,0.75,1$ and $2.5 \mathrm{mg} / \mathrm{ml}$ for 12 and $24 \mathrm{~h}$. Each group was repeated in 9 separate wells. Following treatment, $15 \mu \mathrm{l}$ MTT reagent $(5 \mathrm{mg} / \mathrm{ml})$ was added to each well for $4 \mathrm{~h}$, and then $150 \mu \mathrm{l}$ DMSO was added to each well.
Absorbance was detected at a wavelength of $490 \mathrm{~nm}$ using a microplate reader.

Statistical analysis. Results are expressed as the mean \pm standard error of the mean. Statistical differences were assessed with the unpaired 2-tailed Student's t-test for two experimental groups and one-way ANOVA for multiple groups, using SPSS 19.0 software (IBM Corp, Armonk, NY, USA). Bonferroni's post-hoc test was employed following one-way ANOVA for determining significant differences between groups. A two-tailed P-value of $<0.05$ was considered to indicate a statistically significant difference. Statistical analyses were performed using GraphPad Prism (version 5; GraphPad Software).

\section{Results}

KFX increases the mRNA expression level of tumor-suppressor factor PPAR- $\gamma$ and impairs the viability of SGC-7901 cells. PPAR- $\gamma$, a member of the nuclear receptor superfamily, regulates lipid metabolism, inflammation and cancer progression (19). Usually, PPAR- $\gamma$ regulates target genes by binding to the PPAR $-\gamma$ response element in the promoter region of target genes, resulting in either promotion or inhibition. PPAR- $\gamma$ displays antitumor effects through inhibition of proliferation and induction of differentiation and apoptosis by targeting tumor-associated genes, including tumor protein p63, tumor protein $\mathrm{p} 73$, tumor protein $\mathrm{p} 21$, B-cell lymphoma 2 (Bcl-2), Bcl-2 associated X (Bax), caspase-3 and MYC proto-oncogene $(17,20-22)$. It has been demonstrated that PPAR- $\gamma$ 

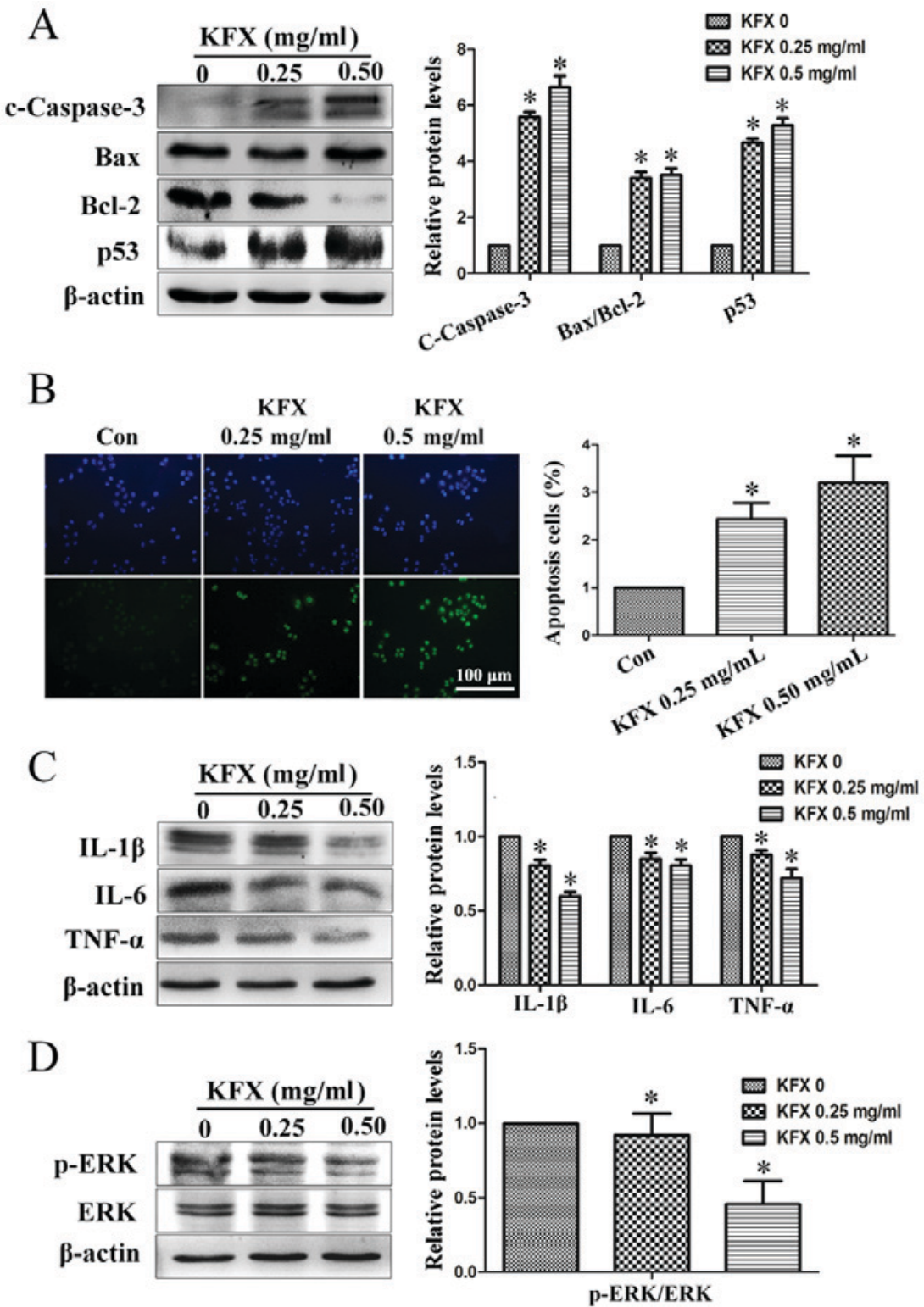

Figure 2. KFX induces cell apoptosis, inhibits the inflammation response and prevents ERK phosphorylation. SGC-7901 cells were treated with KFX at different dosages $(0,0.25$ and $0.5 \mathrm{mg} / \mathrm{ml})$ for $12 \mathrm{~h}$ and (A) the protein levels of c-caspase-3, Bax/Bcl-2 and p53 were detected using western blot analysis. The histogram is the quantitative analysis of the corresponding immunoblots and the data are expressed as fold over control group; $n=6$ for each group. Data are presented as the mean \pm standard error of the mean. ${ }^{*} \mathrm{P}<0.05$ compared with $\mathrm{KFX}(0 \mathrm{mg} / \mathrm{ml})$. (B) DAPI (top) staining and TUNEL assay (bottom) of the SGC-7901 cell treated with KFX at different dosages $(0,0.25$ and $0.5 \mathrm{mg} / \mathrm{ml})$ for $12 \mathrm{~h}$. The histogram is the quantitative analysis of TUNEL + cells in at least 6 separate fields; $\mathrm{n}=6$ for each group. Scale bar, $100 \mu \mathrm{m}$. ${ }^{*} \mathrm{P}<0.05$ compared with control. Western blot assays of (C) IL-6, IL- $1 \beta$ and TNF- $\alpha$, and (D) $\mathrm{p}-\mathrm{ERK} / \mathrm{ERK}$ levels in SGC-7901 cell treated with KFX at different dosages $(0,0.25$ and $0.5 \mathrm{mg} / \mathrm{ml})$ for $12 \mathrm{~h}$. The histogram is the quantitative analysis of the corresponding immunoblots and the data are expressed as fold over control group; $\mathrm{n}=6$ for each group. Data are presented as the mean \pm standard error of the mean. ${ }^{*} \mathrm{P}<0.05$ compared with KFX $(0 \mathrm{mg} / \mathrm{ml})$. KFX, Kangfuxin; TUNEL, terminal deoxynucleotidyl transferase dUTP-mediated nick-end labeling; p-ERK, phosphorylated extracellular signal-regulated kinase; c-caspcase-3, cleaved caspase-3; Bcl-2, B-cell lymphoma 2; Bax, Bcl-2 associated X; IL, interleukin; TNF, tumor necrosis factor; con, control.

activation inhibits cell growth (23) and promotes differentiation and apoptosis in a variety of types of cancer cell.

To investigate whether KFX treatment may lead to the upregulation of PPAR- $\gamma$, RT-qPCR analysis was conducted for SGC-7901 cells treated with KFX at 0, 0.25, 0.5 and $2.5 \mathrm{mg} / \mathrm{ml}$ for 12 and $24 \mathrm{~h}$. As presented in Fig. 1A, PPAR- $\gamma$ mRNA expression level was significantly increased at all concentrations after $24 \mathrm{~h}$ and at $2.5 \mathrm{mg} / \mathrm{ml}$ after $12 \mathrm{~h}$ of KFX treatment, compared with that of the control, in a dose-dependent manner $(\mathrm{P}<0.05)$; no significant differences were identified between the control and cells treated with 0.25 or $0.5 \mathrm{mg} / \mathrm{ml}$ after
$12 \mathrm{~h}$. In addition, cell viability was analyzed by MTT assay. The results demonstrated that exposure to KFX resulted in a dose-dependent decrease in cell viability in the SGC-7901 cells. The half maximal inhibitory concentration values of $\mathrm{KFX}$ at 12 and $24 \mathrm{~h}$ were $1.19 \pm 0.06$ and $0.64 \pm 0.04 \mathrm{mg} / \mathrm{ml}$ $(\mathrm{P}<0.05)$, respectively, for the SGC-7901 cells (Fig. 1B).

KFX induces apoptosis and decreases inflammation in $S G C-7901$ cells. To investigate the hypothesis that KFX is capable of inducing apoptosis in SGC-7901 cells, caspase-3 activity was detected using western blot analysis following 

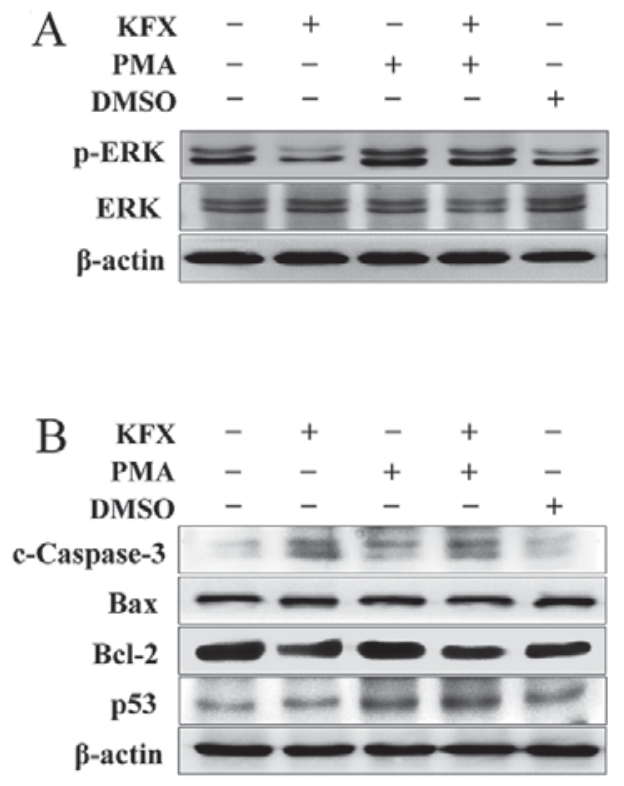
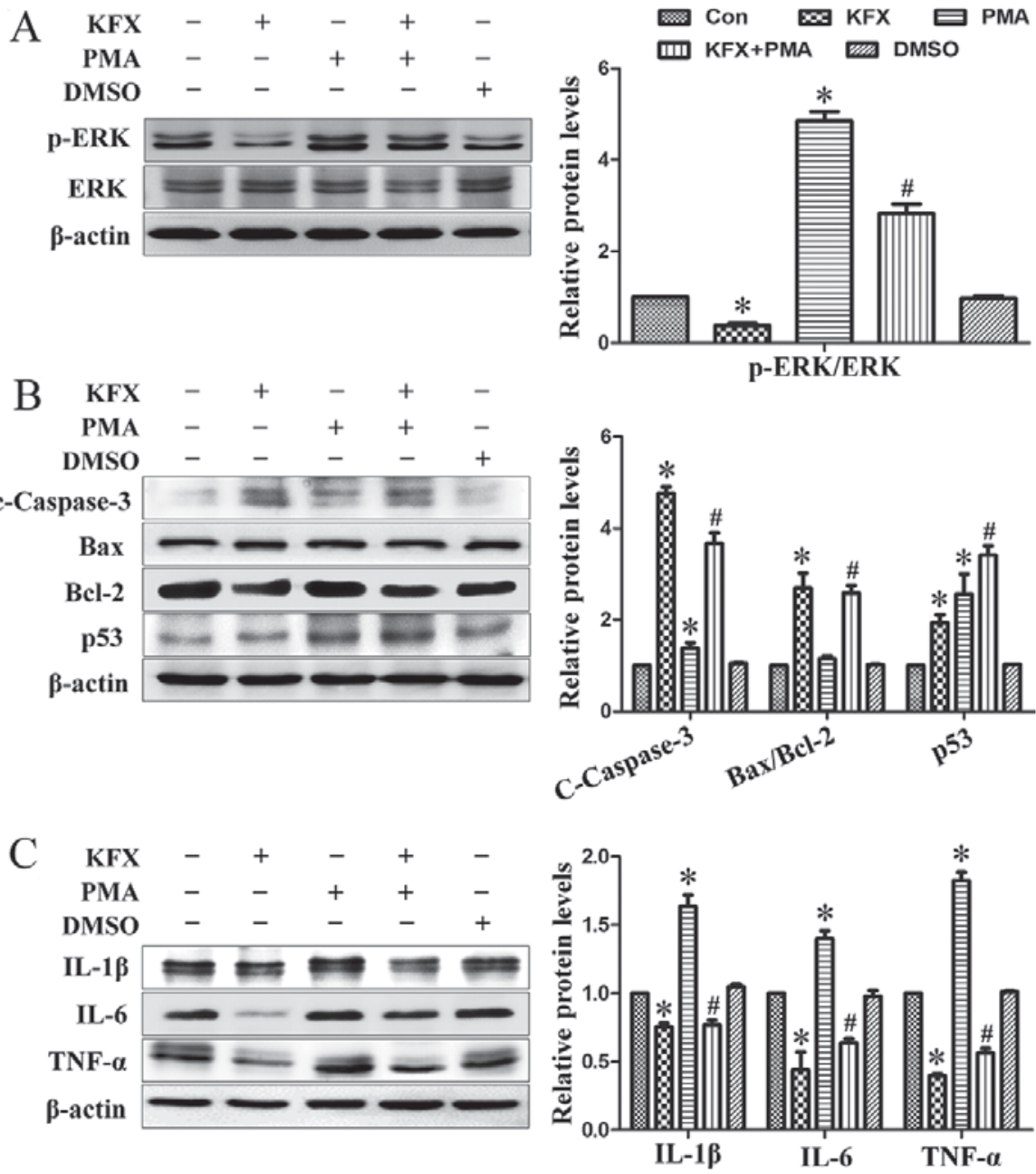

Figure 3. KFX prevents ERK phosphorylation-mediated anti-apoptotic and inflammatory responses. SGC-7901 cells were cultured to near (80-90\%) confluence and then administrated with $0.5 \mathrm{mg} / \mathrm{ml} \mathrm{KFX}$ in the presence or absence of $3 \mathrm{nmol} / 1 \mathrm{PMA}$ for $12 \mathrm{~h}$. Immunoblotting assays of (A) p-ERK/ERK; (B) c-caspase-3, Bax/Bcl-2 and p53; (C) IL-6, IL-1 $\beta$ and TNF- $\alpha$ in SGC-7901 cells. The histogram is the quantitative analysis of the corresponding immunoblots and the data are expressed as fold over control group; $n=6$ for each group. Data are presented as the mean \pm standard error of the mean. ${ }^{*} \mathrm{P}<0.05$ compared with control; ${ }^{\text {"P}} \mathrm{P}$ 0.05 compared with PMA. KFX, Kangfuxin; p-ERK, phosphorylated extracellular signal-regulated kinase; c-caspcase-3, cleaved caspase-3; Bcl-2, B-cell lymphoma 2; Bax, Bcl-2 associated X; IL, interleukin; p53, tumor protein p53; TNF, tumor necrosis factor; PMA, phorbol 12-myristate 13-acetate; DMSO, dimethyl sulfoxide; con, control.

treatment with $0,0.25$ or $0.50 \mathrm{mg} / \mathrm{ml} \mathrm{KFX}$ for $12 \mathrm{~h}$. Activated caspase-3, denoted by increased expression of cleaved caspase-3, was detected in the SGC-7901 cells following KFX treatment (Fig. 2A); this difference was significant compared with the negative control $(\mathrm{P}<0.05)$. Furthermore, to demonstrate the capability of KFX to induce apoptosis in SGC-7901 cells, the pro-survival protein Bcl-2 and the pro-apoptotic protein Bax were evaluated using western blot analysis. A decrease in the expression of Bcl-2 was revealed with KFX treatment; however, Bax expression appeared to remain unaffected. Additionally, the expression levels of p53, an initiator of cellular apoptosis, were upregulated in SGC-7901 cells following KFX treatment (Fig. 2A). These results suggested that the decrease in cell viability observed was due to cell apoptosis induced by KFX. Furthermore, a TUNEL assay was performed to detect the pro-apoptotic effect of KFX on SGC-7901 cells. Compared with the untreated control, the number of apoptosis cells was significantly increased following KFX treatment, in a dose-dependent manner (Fig. 2B).
The magnitude of inflammation is often augmented during aging and age, in turn, is a major risk factor for developing oncological diseases (24). Previous studies have demonstrated that interleukin (IL)-1 $\beta$, IL-6 and tumor necrosis factor (TNF)- $\alpha$ recruit immune cells into the site of a developing tumor or tumor microenvironment, thereby enhancing inflammation $(25,26)$. To investigate the ability of KFX to abate inflammation in the microenvironment of SGC-7901 cells, the expression of IL-1 $\beta$, IL- 6 and TNF- $\alpha$ were detected with western blot analysis in the present study. Fig. $2 \mathrm{C}$ shows that IL-1 $\beta$, IL-6 and TNF- $\alpha$ protein levels significantly decreased following KFX treatment compared with the levels in the untreated cells. These results indicated that KFX may alleviate the production of inflammatory cytokines in SGC-7901 cells.

KFX promotes SGC-7901 cell apoptosis through the ERK pathway. Mitogen-activated protein kinase kinase (MAPKK) is involved in a number of cellular biological functions, including proliferation, differentiation, motility and 


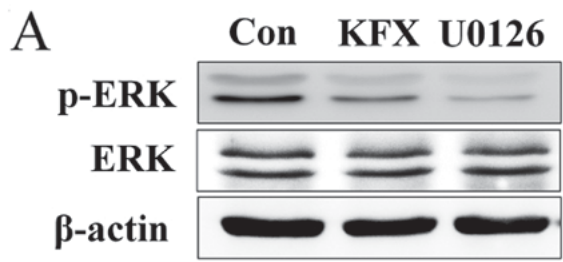

B

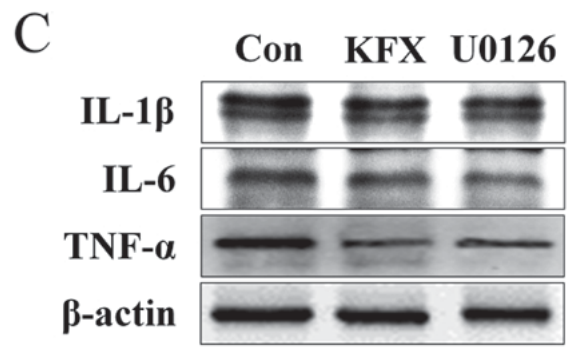

Con KFX U0126
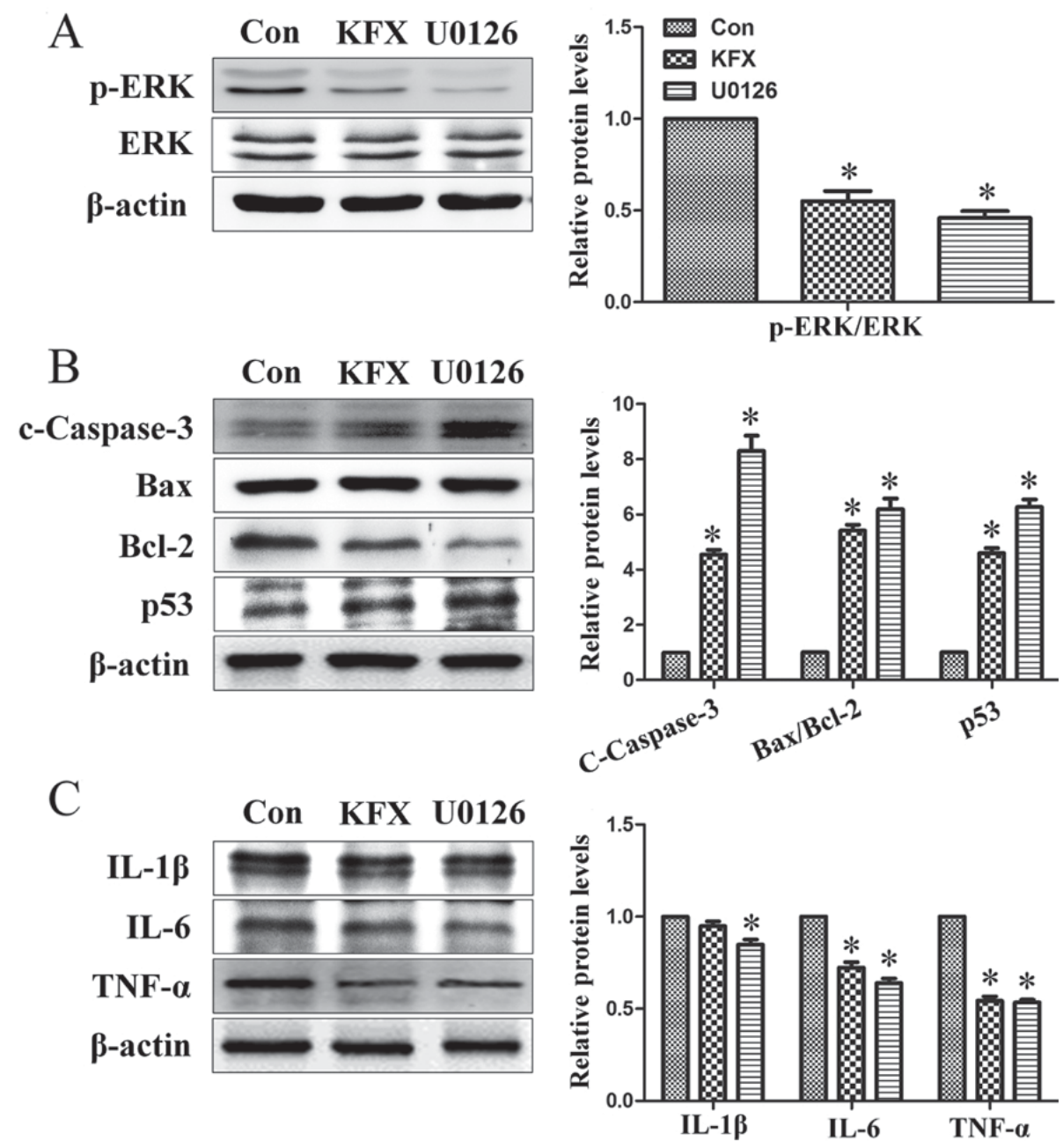

Figure 4. KFX inhibits ERK1/2 pathway phosphorylation similar to U0126. SGC-7901 cells were cultured to near (80-90\%) confluence and then administered with $0.5 \mathrm{mg} / \mathrm{ml} \mathrm{KFX}$ or $0.2 \mu \mathrm{mol} / 1 \mathrm{U} 0126$ for $12 \mathrm{~h}$. Immunoblotting assays of (A) p-ERK/ERK; (B) c-caspase-3, Bax/Bcl-2 and p53; (C) IL-6, IL-1 $\beta$ and TNF- $\alpha$ levels in SGC-7901 cells. The histogram is the quantitative analysis of the corresponding immunoblots and the data are expressed as fold over control group; $\mathrm{n}=6$ for each group. Data are presented as the mean \pm standard error of the mean. " $\mathrm{P}<0.05$ compared with Con. KFX, Kangfuxin; $\mathrm{p}$-ERK, phosphorylated extracellular signal-regulated kinase; p53, tumor protein p53; c-caspcase-3, cleaved caspase-3; Bcl-2, B-cell lymphoma 2; Bax, Bcl-2 associated X; IL, interleukin; TNF, tumor necrosis factor; con, control.

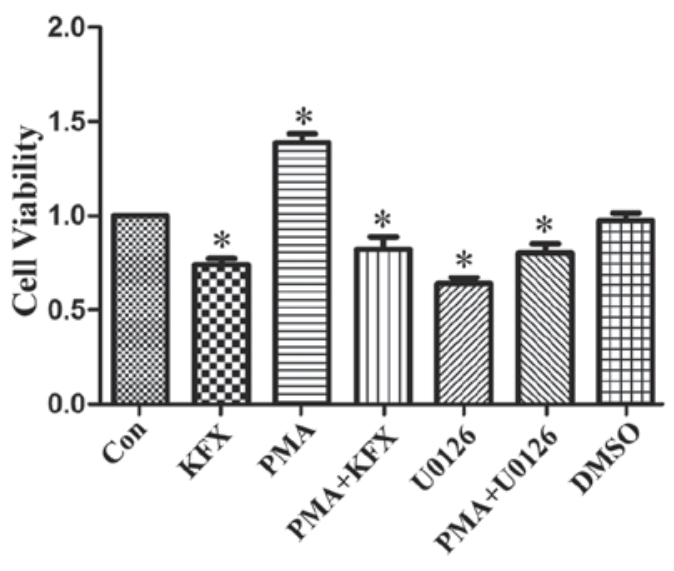

Figure 5. KFX prevents extracellular signal-regulated kinase phosphorylation-mediated cell proliferation. SGC-7901 cells were administrated with $0.5 \mathrm{mg} / \mathrm{ml} \mathrm{KFX}$ for $12 \mathrm{~h}$. Additionally, SGC-7901 cells were co-incubated with $0.2 \mu \mathrm{mol} / 1 \mathrm{U} 0126$ or $3 \mathrm{nmol} / 1 \mathrm{PMA}$ for $12 \mathrm{~h}$. The anti-proliferation effect of KFX was measured using an MTT assay. The histogram is the quantitative analysis of the corresponding cell viability and the data are expressed as fold over control group; $\mathrm{n}=6$ for each group. Data are presented as the mean \pm standard error of the mean. "P<0.05 vs. control group. KFX, Kangfuxin; PMA, phorbol 12-myristate 13-acetate; DMSO, dimethyl sulfoxide; con, control.

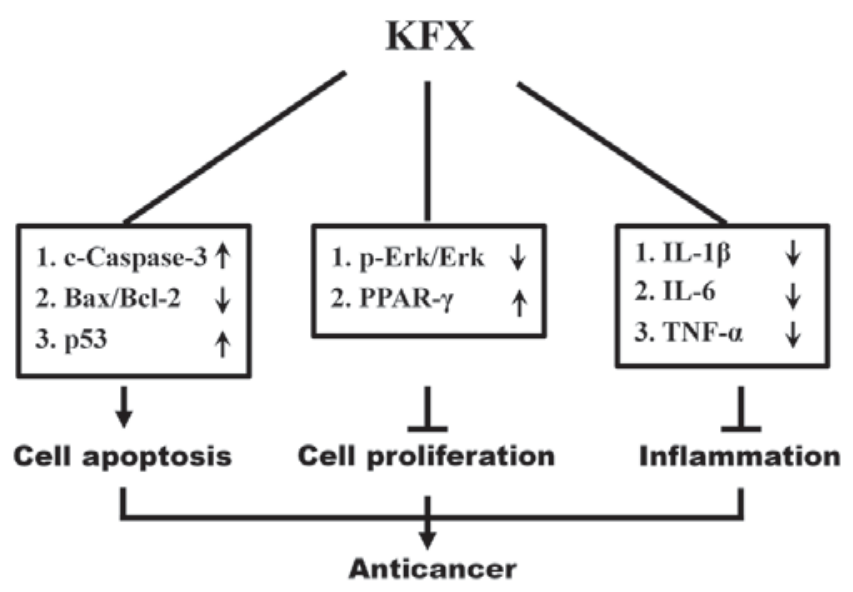

Figure 6. Schematic diagram illustrating the mechanism of KFX pro-apoptotic effects on SGC-7901 cells through inhibition of the MEK/ERK signaling pathway. MEK, mitogen-activated protein kinase/extracellular-signal-regulated kinase kinase; KFX, Kangfuxin; p-ERK, phosphorylated extracellular signal-regulated kinase; c-caspcase-3, cleaved caspase-3; p53, tumor protein p53; Bcl-2, B-cell lymphoma 2; Bax, Bcl-2 associated X; IL, interleukin; TNF, tumor necrosis factor; PPAR- $\gamma$, peroxisome proliferator-activated receptor. 
death (27-29). ERKs are the main members of the MAPKK signaling pathway, and the activation of ERK1/2 is an anticancer target $(30,31)$. Therefore, to clarify whether the ERK signaling pathway is activated in SGC-7901 cells by KFX, cells were treated with $0,0.25$ and $0.5 \mathrm{mg} / \mathrm{ml} \mathrm{KFX}$ for $12 \mathrm{~h}$ in the present study. The results demonstrated that phosphorylated (p)-ERK1/2 was significantly decreased following KFX treatment, in a dose-depended manner, whereas total ERK expression remained consistent (Fig. 2D).

To further investigate the role of $\mathrm{p}-\mathrm{ERK} 1 / 2$ in KFX-mediated SGC-7901 cell apoptosis, PMA, a specific activator of protein kinase $\mathrm{C}, \mathrm{NF}-\kappa \mathrm{B}$ and ERK, was introduced (32). Following cell treatment with PMA, ERK phosphorylation was markedly increased (Fig. 3A). Additionally, pro-survival protein Bcl-2, inflammatory cytokines IL-1 $\beta$, IL-6 and TNF- $\alpha$, along with the downregulated p53 and cleaved caspase-3, were significantly increased, whereas the pro-survival protein Bax remained unchanged (Fig. 3B and C). As expected, KFX exhibited an inhibitory effect on PMA-induced anti-apoptosis via the ERK signaling pathway, as demonstrated by the decreased expression following use of KFX and PMA together.

By contrast, U0126, an inhibitor of p-ERK1/2, was used to inhibit p-ERK1/2 expression and to mimic the function of KFX on SGC-7901 cells. Following treatment with U0126, ERK phosphorylation was blocked and cleaved-caspase 3 expression was increased (Fig. 4A and B). Consistent with the results obtained by KFX treatment, U0126 treatment also exhibited a significant pro-apoptotic and anti-inflammatory effect on SGC-7901 cells (Fig. 4C), which suggested that KFX may inhibit phosphorylation in the ERK1/2 signaling pathway, blocking cell proliferation similar to U0126. In addition, the role of ERK-mediated SGC-7901 cell apoptosis and anti-proliferation induced by KFX was further investigated with an MTT assay. Cell viability of SGC-7901 cells incubated with PMA was significantly increased compared with that of the control, but largely abolished by KFX or U0126 (Fig. 5).

\section{Discussion}

Gastric cancer is the fourth most common cause of cancer-associated mortality worldwide, and remains difficult to treat, primarily due to the majority of patients presenting with advanced disease (1). In the USA, stomach malignancy is currently the 15 th most common type of cancer $(33,34)$. Although the majority of chemotherapeutic regimens utilize antineoplastic agents as the clinical standard of care for gastric cancer, patients commonly experience a limited response to this therapy (35-37). Therefore, investigation into more effective therapeutic interventions for gastric cancer is important. Over the last 50 years, emerging evidence has suggested that a number of natural extracts from plants and animals exhibit beneficial effects in the prevention of cancer $(16,38,39)$. The present study demonstrated that KFX, an aqueous extract from $P$. americana, exhibited potential anticancer effects in a gastric cancer cell line through inhibiting cell proliferation and inducing apoptosis; potentially via the ERK signaling pathway.

The results of the present study demonstrated that KFX markedly inhibited SGC-7901 cell viability in a dose-dependent manner, which indicated that KFX may exhibit a therapeutic effect on gastric cancer. The induction of cellular apoptosis in malignant cells is critical for the chemoprevention and chemotherapy of cancer by natural product-derived anticancer agents $(40,41)$; as such, the inhibition of SGC-7901 cell viability following KFX treatment may be as a result of apoptosis. Therefore, in order to clarify the underlying molecular mechanism, the effect of KFX treatment on SGC-7901 cell apoptosis was investigated. In general, apoptosis is a type of organized cell self-destruction by a series of signal cascades that include numerous gene products and cytokines. Caspase-3 activation serves an important role in apoptosis, whilst the imbalance between Bcl-2 (anti-apoptotic) and Bax (pro-apoptotic) has been recognized as a signature of the acquisition of apoptosis resistance in cancer cells $(42,43)$. In addition, p53, acting as a transcriptional factor, serves an important role in promoting apoptosis in response to various cellular stressors, including oncogene activation (44). The results of the present study demonstrated that KFX may induce gastric cancer cell apoptosis, supported by the observed caspase-3 activation, p53 upregulation and $\mathrm{Bcl}-2$ downregulation alongside unchanged Bax expression.

ERK is involved in a number of cellular programs, and the activation of ERK through phosphorylation is a potential anticancer target (45). In the present study, it was revealed that KFX possessed anticancer potential in SGC-7901 cells through inhibiting cell proliferation and inducing apoptosis, potentially via the ERK signaling pathway. KFX exhibited an inhibitory effect on protein kinases involved in the phosphorylation of ERK, thereby leading to a decrease in p-ERK protein. Furthermore, following incubation with an ERK activator, PMA, the decrease observed in cleaved caspase-3 and p53, and the increase in Bcl-2, inflammatory cytokines and cell proliferation, suggested that KFX-induced apoptosis may occur via an ERK-mediated signaling pathway. Referring to the results of the present study and the relevant information available in the literature, a proposed scheme presenting a potential explanation regarding the pro-apoptotic effect of KFX on SGC-7901 cells was created (Fig. 6).

In conclusion, to the best of our knowledge, the results of the present study demonstrated for the first time that KFX may potentially inhibit SGC-7901 gastric cancer cell proliferation and induce apoptosis through modulation of the ERK signaling pathway, thus suggesting the novel therapeutic potential of KFX for gastric cancer treatment.

\section{Acknowledgements}

Not applicable.

\section{Funding}

The present study was supported by the National Nature Science Foundation of China (grant no. 81570368), Technology Program of Wenzhou (grant no. Y20140737) and Wenzhou Medical University Crossing Research Program (grant no. KJHX1504).

\section{Availability of data and materials}

The datasets used and/or analyzed during the current study are available from the corresponding author on reasonable request. 


\section{Authors' contributions}

WC and FG conceived the present study. XM and JS wrote the manuscript and performed the cell cultures. WY performed the western blot analysis. YH conducted the cell apoptosis assays. CS performed and analyzed the PCR. YT and TW performed the western blot analysis and MTT assays. All authors read and approved the final manuscript.

\section{Ethics approval and consent to participate}

Not applicable.

\section{Consent for publication}

Not applicable.

\section{Competing interests}

The authors declare that they have no competing interests.

\section{References}

1. Yu J, Wang X, Li Y and Tang B: Tanshinone IIA suppresses gastric cancer cell proliferation and migration by downregulation of FOXM1. Oncol Rep 37: 1394-1400, 2017.

2. de Martel C, Eorman D and Plummer M: Gastric cancer: Epidemiology and risk factors. Gastroenterol Clin North Am 42: 219-240, 2013.

3. Zheng HC, Zheng YS, Li XH, Takahashi H, Hara T, Masuda S, Yang XH, Guan YF and Takano Y: Arp2/3 overexpression contributed to pathogenesis, growth and invasion of gastric carcinoma. Anticancer Res 28: 2225-2232, 2008.

4. Sherr CJ: Principles of tumor suppression. Cell 116: 235-246, 2004.

5. André T, Boni C, Navarro M, Tabernero J, Hickish T, Topham C, Bonetti A, Clingan P, Bridgewater J, Rivera F and de Gramont A: Improved overall survival with oxaliplatin, fluorouracil, and leucovorin as adjuvant treatment in stage II or III colon cancer in the MOSAIC trial. J Clin Oncol 27: 3109-3116, 2009.

6. Chinese Materia Medica Editoral Committee: Chinese Materia Medica. Vol 9. Shanghai Scientific and Technical Publisher, Shanghai, pp149-151, 1999.

7. Sun XY: Sheng Nong's herbal classic. Beijing Commercial Press, Beijing, pp90-91, 1955.

8. Jiang Y, Wang X, Jin C, Chen X, Li J, Wu Z, Liu G and Li S: Inhibitory effect of Periplaneta Americana extract on 3LL lung cancer in mice. Zhongguo Fei Ai Za Zhi 9: 488-491, 2006 (In Chinese)

9. Li W, Duan LF, He GQ, Shen ZQ, Yang HQ and Liang YP: Periplaneta americana extract effects on experimental liver fibrosis. Lishizhen Med Mater Med Res 21: 1137-1138, 2010.

10. He ZC, Peng F, Song LY, Wang XY, Hu MH, Zhao Y and Liu GM: Review on investigations related to chemical constituents and biological activities of Periplaneta americana. Zhongguo Zhong Yao Za Zhi 32: 2326-2331, 2007 (In Chinese).

11. Sun YN: Apoptosis pathway for targets of anti-tumor treatment research progress. Foreign Med Sci (Sect Pharmarcy) 33: 321-324, 2006

12. Chen P, Shen Y, Shi H, Ma X, Lin B, Xiao T, Wu F, Zhu J, Li Z, Xiao J, et al: Gastroprotective effects of Kangfuxin-against ethanol-induced gastric ulcer via attenuating oxidative stress and ER stress in mice. Chem Biol Interact: Oct 28, 2016 (Epub ahead of print).

13. Luo SL, Huang XJ, Wang Y, Jiang RW, Wang L, Bai LL, Peng QL, Song CL, Zhang DM and Ye WC: Isocoumarins from American cockroach (Periplaneta americana) and their cytotoxic activities. Fitoterapia 95: 115-120, 2014.

14. Zhang H, Wei L, Zhang Z, Liu S, Zhao G, Zhang J and Hu Y: Protective effect of Periplaneta americana extract on intestinal mucosal barrier function in patients with sepsis. J Tradit Chin Med 33: 70-73, 2013.
15. Yuan F, Liu J, Qiao T, Li T, Shen Q and Peng F: The effects and mechanisms of Periplaneta americana extract reversal of multi-drug resistance in BEL-7402/5-FU cells. Molecules 21: pii: E852, 2016.

16. Chen PP, Ma XY, Lin Q, Xu HL, Shi HX, Zhang HY, Xiao J, Geng FN and Zhao YZ: Kangfuxin promotes apoptosis of gastric cancer cells through activating ER-stress and autophagy. Mol Med Rep 16: 9043-9050, 2017.

17. Kim S, Lee JJ and Heo DS: PPAR $\gamma$ ligands induce growth inhibition and apoptosis through p63 and p73 in human ovarian cancer cells. Biochem Biophys Res Commun 406: 389-395, 2011.

18. Tsai CY, Wang CC, Lai TY, Tsu HN, Wang CH, Liang HY and Kuo WW: Antioxidant effects of diallyl trisulfide on high glucose-induced apoptosis are mediated by the PI3K/Akt-dependent activation of Nrf2 in cardiomyocytes. Int J Cardiol 168: 1286-1297, 2013.

19. Kersten S, Desvergne B and Wahli W: Roles of PPARs in health and disease. Nature 405: 421-424, 2000.

20. Brown CJ, Lain S, Verma CS, Fersht AR and Lane DP: Awakening guardian angels: Drugging the p53 pathway. Nat Rev Cancer 9: 862-873, 2009.

21. Akinyeke TO and Stewart LV: Troglitazone suppresses c-Myc levels in human prostate cancer cells via a PPAR $\gamma$-independent mechanism. Cancer Biol Ther 11: 1046-1058, 2011.

22. Na HK and Surh YJ: Peroxisome proliferator-activated receptor gamma (PPARgamma) ligands as bifunctional regulators of cell proliferation. Biochem Pharmacol 66: 1381-1391, 2003.

23. Garcia-Bates TM, Lehmann GM, Simpson-Haidaris PJ, Bernstein SH, Sime PJ and Phipps RP: Role of peroxisome proliferator-activated receptor gamma and its ligands in the treatment of hematological malignancies. PPAR Res 2008: 834612, 2008.

24. Dmitrieva OS, Shilovskiy IP, Khaitov MR and Grivennikov SI: Interleukins 1 and 6 as main mediators of inflammation and cancer. Biochemistry (Mosc) 81: 80-90, 2016.

25. Tawara K, Oxford JT and Jorcyk CL: Clinical significance of interleukin (IL)-6 in cancer metastasis to bone: potential of anti-IL-6 therapies. Cancer Manag Res 3: 177-189, 2011.

26. Chang Q, Bournazou E, Sansone P, Berishaj M, Gao SP, Daly L, Wels J, Theilen T, Granitto S, Zhang X, et al: The IL-6/JAK/Stat3 feed-forward loop drives tumorigenesis and metastasis. Neoplasia 15: 848-862, 2013.

27. Yang $M$ and Huang CZ: Mitogen-activated protein kinase signaling pathway and invasion and metastasis of gastric cancer. World J Gastroenterol 21: 11673-11679, 2015.

28. Ji CD, Wang YX, Xiang DF, Liu Q, Zhou ZH, Qian F, Yang L, Ren Y, Cui W, Xu SL, et al: Kir2.1 interaction with Stk38 promotes invasion and metastasis of human gastric cancer by enhancing MEKK2-MEK1/2-ERK1/2 signaling. Cancer Res: Mar 16, 2018 (Epub ahead of print).

29. Shin BA, Yoo HG, Kim HS, Kim MH, Hwang YS, Chay KO, Lee KY, Ahn BW and Jung YD: P38 MAPK pathway is involved in the urokinase plasminogen activator expression in human gastric SNU-638 cells. Oncol Rep 10: 1467-1471, 2003.

30. Rubinfeld $\mathrm{H}$ and Seger R: The ERK cascade: A prototype of MAPK signaling. Mol Biotechnol 31: 151-174, 2005.

31. Murphy LO and Blenis J: MARK signal specificity: the right place at the right time. Trends Biochem Sci 31: 268-275, 2006.

32. Zhang L, Stuber F, Lippuner C, Schiff $M$ and Stamer UM: Phorbol-12-myristate-13-acetate induces nociceptin in human Mono Mac 6 cells via multiple transduction signalling pathways. Br J Anaesth 117: 250-257, 2016.

33. World Health Organization (WHO): Cancer: Fact Sheet No 297. WHO, Geneva, 2015. http://www.who.int/mediacentre/factsheets/fs297/en/. Accessed, May 21, 2015.

34. National Cancer Institute (NCI): Cancer Stat Facts: Stomach Cancer. NCI, Bethesda, MD, 2015. http://seer.cancer.gov/statfacts/html/stomach.html. Accessed, May 21, 2015.

35. Nishikawa K, Tsuburaya A, Yoshikawa T, Takahashi M, Tanabe K, Yamaguchi K, Yoshino S, Namikawa T, Aoyama T, Rino Y, et al: A phase II trial of capecitabine plus cisplatin (XP) for patients with advanced gastric cancer with early relapse after S-1 adjuvant therapy: XParTS-I trial. Gastric Cancer: Feb 27, 2018 (Epub ahead of print).

36. Abdel-Razeq H, Mansour A, Abdulelah H, Al-Shwayat A, Makoseh M, Ibrahim M, Abunasser M, Rimawi D, Al-Rabaiah A, Alfar R et al: Thromboembolic events in cancer patients on active treatment with cisplatin-based chemotherapy: Another look! Thromb J 16: 2, 2018. 
37. Kim SM and Park SH: Chemotherapy beyond second-line in advanced gastric cancer. World J Gastroenterol 21:8811-8116,2015.

38. Budchart P, Khamwut A, Sinthuvanich C, Ratanapo S, Poovorawan Y and T-Thienprasert NP: Partially purified gloriosa superba peptides inhibit colon cancer cell viability by inducing apoptosis through $\mathrm{p} 53$ upregulation. Am J Med Sci 354: 423-429, 2017.

39. Lin SR, Fu YS, Tsai MJ, Cheng H and Weng CF: Natural compounds from herbs that can potentially execute as autophagy inducers for cancer therapy. Int J Mol 18: pii: E1412, 2017.

40. Zhu X, Li Z, Li T, Long F, Lv Y, Liu L, Liu X and Zhan Q: Osthole inhibits the PI3K/AKT signaling pathway via activation of PTEN and induces cell cycle arrest and apoptosis in esophageal squamous cell carcinoma. Biomed Pharmacother 102: 502-509, 2018.

41. Maryam A, Mehmood T, Yan Q, Li Y, Khan M and Ma T: Proscillaridin a promotes oxidative stress and ER stress, inhibits STAT3 activation and induces apoptosis in A549 lung adenocarcinoma cells. Oxid Med Cell Longev 2018: 3853409, 2018

42. Yu J, Peng H, Lin Y and Yi S: Effect of moxibustion treatment on cell apoptosis and expressions of heat shock protein and second mitochondrial activator of caspase in acute gastric mucosal lesion of rats. J Tradit Chin Med 33: 258-261, 2013.
43. Zhang R, He Y, Zhang X, Xing B, Sheng Y, Lu H and Wei Z: Estrogen receptor-regulated microRNAs contribute to the BCL2/BAX imbalance in endometrial adenocarcinoma and precancerous lesions. Cancer Lett 314: 155-165, 2012.

44. Harris BRE, Wang D, Zhang Y, Ferrari M, Okon A, Cleary MP, Wagner CR and Yang DQ: Induction of the p53 tumor suppressor in cancer cells through inhibition of cap-dependent translation. Mol Cell Biol: Feb 26, 2018 (Epub ahead of print).

45. Baillie TA: Metabolism and toxicity of drugs. Two decades of progress in industrial drug metabolism. Chem Res Toxicol 21: 129-137, 2008.

(c) (i) $\Theta$ This work is licensed under a Creative Commons EY NO ND Attribution-NonCommercial-NoDerivatives 4.0 International (CC BY-NC-ND 4.0) License. 